\title{
ECOLOGICAL EFFECTS OF THE FIRST DAM ON YANGTZE MAIN STREAM AND FUTURE CONSERVATION RECOMMENDATIONS: A REVIEW OF THE PAST 60 YEARS
}

\author{
ZHANG, H. ${ }^{1}$ - LI, J. Y. ${ }^{1}-$ WU, J. M. ${ }^{1}-$ WANG, C. Y. ${ }^{1}-$ DU, H. ${ }^{1}-$ WEI, Q. W. ${ }^{1 *}-$ KANG, M. ${ }^{2 *}$ \\ ${ }^{1}$ Key Laboratory of Freshwater Biodiversity Conservation, Ministry of Agriculture of China; \\ Yangtze River Fisheries Research Institute, Chinese Academy of Fishery Sciences, Wuhan, \\ Hubei Province, P. R. China \\ (phone: +86-27-8178-0118; fax: +86-27-8178-0118) \\ ${ }^{2}$ Department of Maritime Police and Production System / The Institute of Marine Industry, \\ Gyeongsang National University, Cheondaegukchi-Gil 38, Tongyeong-si, Gyeongsangnam-do, \\ 53064, South Korea \\ (phone: +82-55-772-9187; fax: +82-55-772-9189) \\ *Corresponding authors \\ e-mail:weiqw@yfi.ac.cn;mk@gnu.ac.kr \\ (Received 21 ${ }^{\text {st }}$ Jul 2017; accepted $27^{\text {th }}$ Oct 2017)
}

\begin{abstract}
The Gezhouba Dam was the first and lowermost dam on the major stem of the Yangtze River. Up to now, the dam has been operating for more than 35 years. The time period was a fast economic development stage in the Yangtze basin. Therefore, the entire Yangtze aquatic ecosystem has been highly affected by various anthropogenic activities. Especially, the fish population and distribution in the Yangtze River have been largely altered. This study reviews the ecological effects of the Gezhouba Dam to the Yangtze aquatic biodiversity for the past 60 years based on literatures. It was concluded that the pre-assessment of the Gezhouba Dam on Yangtze fishes in 1970s was appropriate. Blocking the migration of migratory fishes, such as Chinese sturgeon Acipenser sinensis, and the four major Chinese carps, was a critical adverse effect. Currently, the Yangtze aquatic biodiversity is facing further problems not only the existence of the Gezhouba Dam but also anthropogenic activities. Effective and practical protected measures are recommended and should be conducted urgently to rescue the Yangtze aquatic biodiversity.
\end{abstract}

Keywords: ecological impact assessment, anadromous fish, movement and migration, Gezhouba Dam, Yangtze River

\section{Introduction}

The Yangtze River originates from the Qinghai-Tibet Plateau and connects to the west Pacific. It is the third largest river in the world with more than $6,300 \mathrm{~km}$ in total length and $180 \mathrm{~km}^{2}$ basin area which corresponds approximately one fifth of China mainland size ( $\mathrm{Yu}$ and $\mathrm{Lu}, 2005$ ). It has 437 tributaries with larger than $1,000 \mathrm{~km}^{2}$ of sub-basin area and 22 of them larger than $10,000 \mathrm{~km}^{2}$. The total area of freshwater lakes is larger than $22,000 \mathrm{~km}^{2}$. The annual run off is $960 \times 10^{9} \mathrm{~m}^{3} / \mathrm{s}$. Due to the huge size, the river holds high aquatic biodiversity including about 2,000 aquatic species, thereinto there are approximate 400 fish species (Yang et al., 2007). In the world, it is the only river which holds Acipenseriformes (Chinese sturgeon Acipenser sinensis, Yangtze (Dabry's) sturgeon A. dabryanus, and Chinese paddlefish Psephurus gladius) and Cetacea (Yangtze River dolphin Lipotes vexillifer, Finless porpoise Neophocaena phoconoides).

Due to high elevation variations and abundant runoff, the Yangtze River contains rich water energy. The theoretical reserve of hydraulic resources is $2.78 \times 10^{8} \mathrm{~kW}$, and 
the annual power generation is $2.43 \times 10^{13} \mathrm{kWh}$ (Yang et al., 2007). No hydropower dam on the Yangtze main stem was built until late 1960s. In 1970, the Gezhouba Dam was begun to construct and it blocked the river stream in 1981. It was the first and up to now the lowermost dam in the Yangtze main stem. It should be mentioned that at that time, as the economic difficulties and thought that a fish passage might not have worked effectively, a fish passage was decided not to be built in the end after countrywide discussions and disputes (Chang et al., 1998).

For 35 years, the Gezhouba Dam has been operating and affecting Yangtze aquatic organisms in various aspects. It is speculated that the ecological effects of the dam should have already emerged. Therefore, it should be the right time to review all relevant studies on the first and lowermost dam on the Yangtze main stream. More precisely, a comprehensive review on ecological impacts on the Yangtze aquatic biodiversity on the basis of the existence of the Gezhouba Dam is needed. In this study, we review the ecological impacts of the Gezhouba Dam and the relevant Yangtze aquatic biodiversity for the past 60 years mainly based on literature studies. Furthermore, this study is to re-evaluate whether the original decisions of the Gezhouba Dam's effects on Yangtze aquatic organisms are appropriate, and to examine how the mitigated protection measures recommended were performed. In addition, the future conservation strategies and measures are proposed and discussed on the basis of the current status of Yangtze aquatic biodiversity and threatening factors.

\section{The Yangtze aquatic biodiversity}

In accordance with the first systematic investigation on Yangtze fishes conducted about 60 years ago, approximately 2,000 aquatic species have been reported in the Yangtze Basin (Table 1) (Yang et al., 2007). According to the China Red Book of Endangered Animals, the number of threatened fishes was 69 species (occupied 18.25\% of the entire Chinese endangered fishes), amphibian was 69 species (47.59\%), and reptile was 54 species $(32.53 \%)$. All had the highest threatened ratio among the China inland water areas. In addition, 162 fish species are regarded as endemic species. Many of them are listed as important protected species both inside and outside China (Table 2).

Table 1. Major aquatic organisms in the Yangtze River system (Yang et al., 2007)

\begin{tabular}{c|c|c}
\hline Category & Taxon & Species numbers \\
\hline Algae & Planktonic algae & 321 \\
& Attached algae & $>100$ \\
Aquatic vascular plant & Fern & 6 \\
& Dicotyledon & 89 \\
& Monocotyledon & 119 \\
Zooplankton & Protozoa & 93 \\
& Rotifer & 118 \\
& Cladows & 74 \\
\multirow{2}{*}{ Zoobenthos } & Copepods & 45 \\
& Oral gills & 73 \\
& Gastropods & 56 \\
& Oligochaeta & 13 \\
& Polychaeta & 8 \\
\hline
\end{tabular}




\begin{tabular}{c|c|c}
\hline \multirow{2}{*}{ Nekton } & Aquatic insect & \multicolumn{2}{|c}{60} \\
& Crustacea & 7 \\
Amphibian and reptile & Fish & $378^{*}$ \\
& Mammalia & 3 \\
& Caudata & 23 \\
Waterfowl & Anura & 122 \\
Total & Chelonia & 18 \\
\hline
\end{tabular}

* Includes 16 subspecies. ** Not includes the waterfowl and attached algae.

Table 2. Protected species in the Yangtze Basin

\begin{tabular}{|c|c|c|c|c|c|c|}
\hline No. & Chinese name & English name & Latin name & $\begin{array}{c}\text { Protection level } \\
\text { in China }\end{array}$ & IUCN & CITES \\
\hline 1 & 白既豚 & $\begin{array}{l}\text { Yangtze River } \\
\text { dolphin }\end{array}$ & Lipotes vexillifer & I & CR & I \\
\hline 2 & 白鲟 & $\begin{array}{c}\text { Chinese } \\
\text { paddlefish }\end{array}$ & Psephurus gladius & I & CR & II \\
\hline 3 & 中华鲟 & Chinese sturgeon & Acipenser sinensis & I & CR & II \\
\hline 4 & 达氏鲟 & Dabry's sturgeon & Acipenser dabryanus & I & $\mathrm{CR}$ & II \\
\hline 5 & 扬子鳄 & Chinese alligator & Alligator sinensis & I & $\mathrm{CR}$ & I \\
\hline 6 & 江豚 & Finless porpoise & $\begin{array}{l}\text { Neophocaena } \\
\text { phocaenoides }\end{array}$ & II & VU & I \\
\hline 7 & 胭脂鱼 & Chinese sucker & Myxocyprinus asiaticus & II & l & I \\
\hline 8 & 金线鲃 & Golden line fish & Sinocyclocheilus grahami & II & $\mathrm{CR}$ & / \\
\hline 9 & 大鲵 & $\begin{array}{c}\text { Chinese giant } \\
\text { salamander }\end{array}$ & Andrias davidianus & II & $\mathrm{CR}$ & I \\
\hline 10 & 川陕哲罗鲑 & Sichuan taimen & Hucho bleekeri & II & CR & / \\
\hline 11 & 秦岭细鳞鲑 & Qinling lenok & $\begin{array}{c}\text { Brachymystax lenok } \\
\text { tsinlingensis }\end{array}$ & II & l & I \\
\hline 12 & 松江鲈 & $\begin{array}{l}\text { Rough-skin } \\
\text { sculpin }\end{array}$ & Trachidermus fasciatus & II & l & I \\
\hline 13 & 花鳗鲡 & Giant mottled eel & Anguilla marmorata & II & LC & I \\
\hline
\end{tabular}

Note: IUCN means the International Union for Conservation of Nature, CR (Critically Endangered), VU (Vulnerable) and LC (Least concern) are Red List Categories. CITES indicates the Convention on International Trade in Endangered Species of Wild Flora and Fauna, I or II means in Appendix I or II, respectively.

\section{The Gezhouba Dam and reservoir}

The Gezhouba Dam was located about 1,678 river $\mathrm{km}$ from the Yangtze estuary (river km 0 was at the estuary, Fig. 1). The Gezhouba Dam was constructed from 1970 for 20 years, blocked in 1981, and completely finished in 1990 (Anonymous, 1993; 
CWRC, 2002). It was the largest dam since the P. R. China constructed in 1949. The dam was $2606.5 \mathrm{~m}$ in length, $53.8 \mathrm{~m}$ in height, and $70 \mathrm{~m}$ in elevation. The annual flow discharge at the dam was $14,300 \mathrm{~m}^{3} / \mathrm{s}$, and sediment content was $1.19 \mathrm{~kg} / \mathrm{m}^{3}$. The reservoir capacity was $1.58 \times 10^{10} \mathrm{~m}^{3}$, and adjustable capacity was $0.8 \times 10^{9} \mathrm{~m}^{3}$. The total installed capacity of the power plant was 2,715 MW. The normal water level of the reservoir was $66 \mathrm{~m}$. In flooded season, the length of backwater was approximately 110 $\mathrm{km}$ (to Badong, Hubei Province), and in dry season, the length can be up to $180 \mathrm{~km}$ (to Fengjie, Chongqing Municipality). Additionally, the design of the Gezhouba Dam helped in building the Three Gorges Dam, which is the biggest dam in the world, as an anti-regulated shipping cascaded dam in 1994.
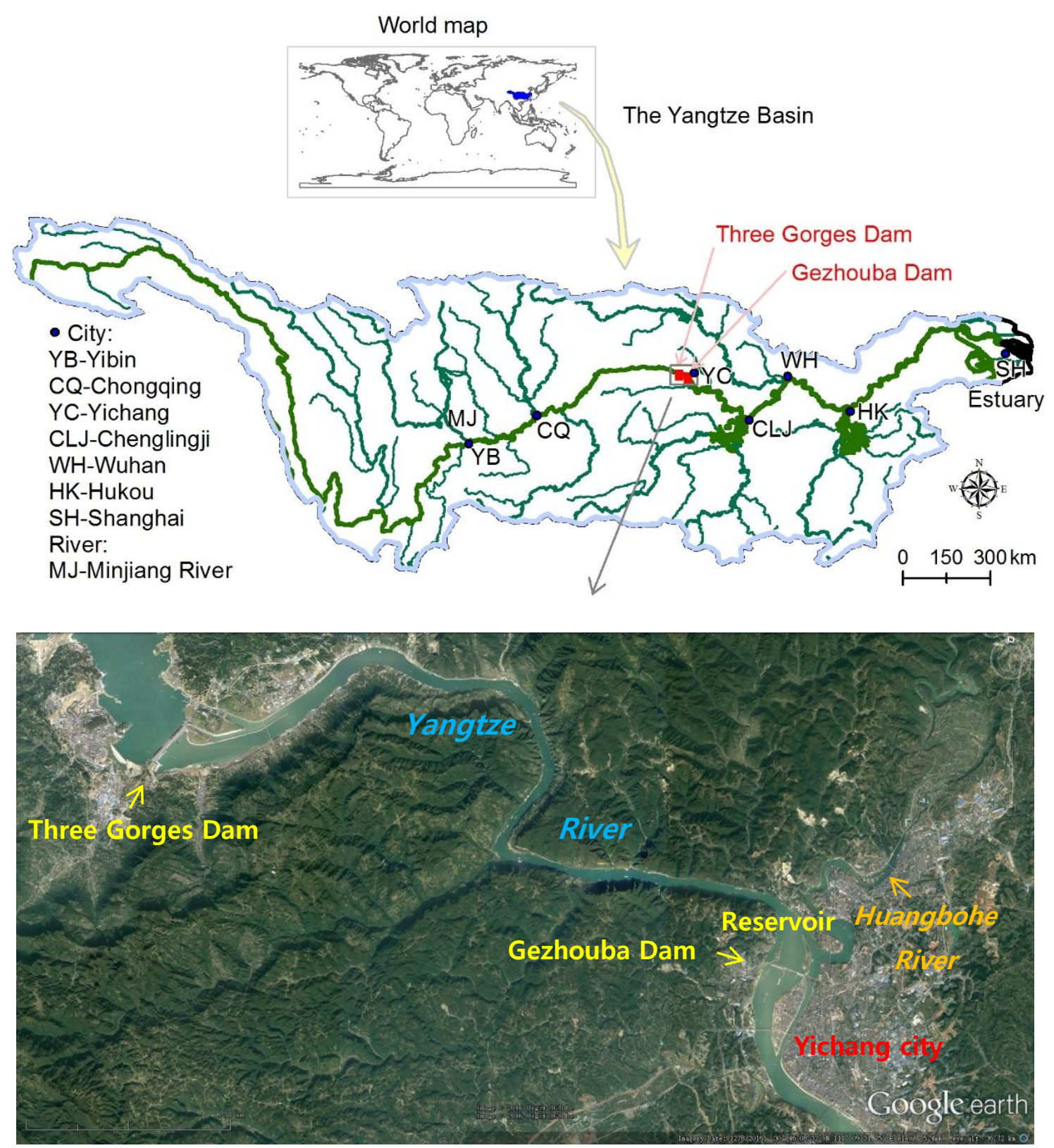

Figure 1. The Gezhouba Dam and reservoir in the Yangtze River Basin 


\section{Impact assessment before the dam construction}

Before the dam was constructed, a series of special studies on fishes and fisheries in the Yangtze Basin had been conducted (FLIHHP, 1976; YARSG, 1988; Yi et al., 1988; Chen et al., 1997). The studies can be summarized into three categories: field surveys, laboratory studies, and theoretical studies. The field surveys included survey on spawning areas of the four major Chinese carps, ecological survey of Chinese sturgeon, and survey on the aquatic organisms in the upper Yangtze main stem. The laboratory studies included fishes, for example Chinese sturgeon, swimming ability for designing a fish passage, and artificial propagation of Chinese sturgeon. The theoretical studies included reviews on fish passages all over the world and plans on fish rescue measures.

These studies concluded that Yichang reach had more than 100 fish species, which was equivalent to approximately one third of the entire Yangtze River fish species. As the Gezhouba Dam was a low-head runoff hydropower station, it might not have changed the hydrological regime and river fluvial habitat significantly. However, blocking the migration route of migratory fishes was the major adverse effect. On the issue on building a fish passage for free migration, national-wide and long-term disputes were aroused. This dispute finally terminated in 1982, when the spawning activity of Chinese sturgeon was confirmed below the Gezhouba Dam (Yu et al., 1985; Chang et al., 1998). Before the dam was closed in 1981, the major conclusions and recommended protection measures on migratory fishes were as follows:

1) The Chinese sturgeon: a fish passage might not have functioned properly for this species, because the species is huge (250-400 cm in length). Even though the species could swim up to the upstream by passing through the passage, a way how they could swim downstream was problematic. On the other hand, if the species might have the ability to adapt to the new environment below the dam, they probably could spawn in the new site. In addition, artificial propagation and releasing could be good methods to increase the population of the species.

2) The four major Chinese carps: as their spawning areas were widely distributed in the entire Yangtze main stem, the dam construction could only destruct the spawning areas near the dam. Blocked population would have spawning in above or below the dam respectively. Therefore, the dam would have had a little adverse effects on them and no further protection was needed.

3) Other freshwater migratory fishes: white bream Parabramis pekinensis, black bream Megalobrama skolkovii, bronze gudgeon Coreius heterodon, and Rhinogobio typus and other species would have migrated among river main stream, tributaries or lakes. Thus, they should have adapted to the new dammed river environment like the four major Chinese carps.

4) Other river-sea migratory fishes: most of Reeves shad Macrura reevesii and Japanese eel Anguilla japonica could not have swum upstream to the dam location, it was speculated that the dam would not have affected obvious adverse effects on them.

\section{Co-effect of other anthropogenic activities}

The Yangtze Basin was one of the most developing zones in China, and it produced approximately $40 \%$ of country's Gross Domestic Product (Yang et al., 2007). Before and after the Gezhouba Dam was constructed, anthropogenic activities imposed various adverse effects on the aquatic ecosystem. The anthropogenic activities included water conservancy projects (other dams), fishing, water pollution, disconnection of river and 
lakes, sand and gravel excavation, navigation, port construction, channelization, bank protection projects, invasion of exotic species (Yang et al., 2007). Fish capture production shows that the overfishing have been occurred since early 1950s (Fig. 2) (SGFRYR, 1990). Fig. 3 shows that the ship cargo volume increased by double in 1980s since the Gezhouba was constructed (Yin et al., 2002; CTGC, 2015). The increase of ship cargo volume implied the increase of ship number, ship size as well as heavy human activities on the water. These were potential threats to Yangtze aquatic biodiversity besides the Gezhouba Dam.
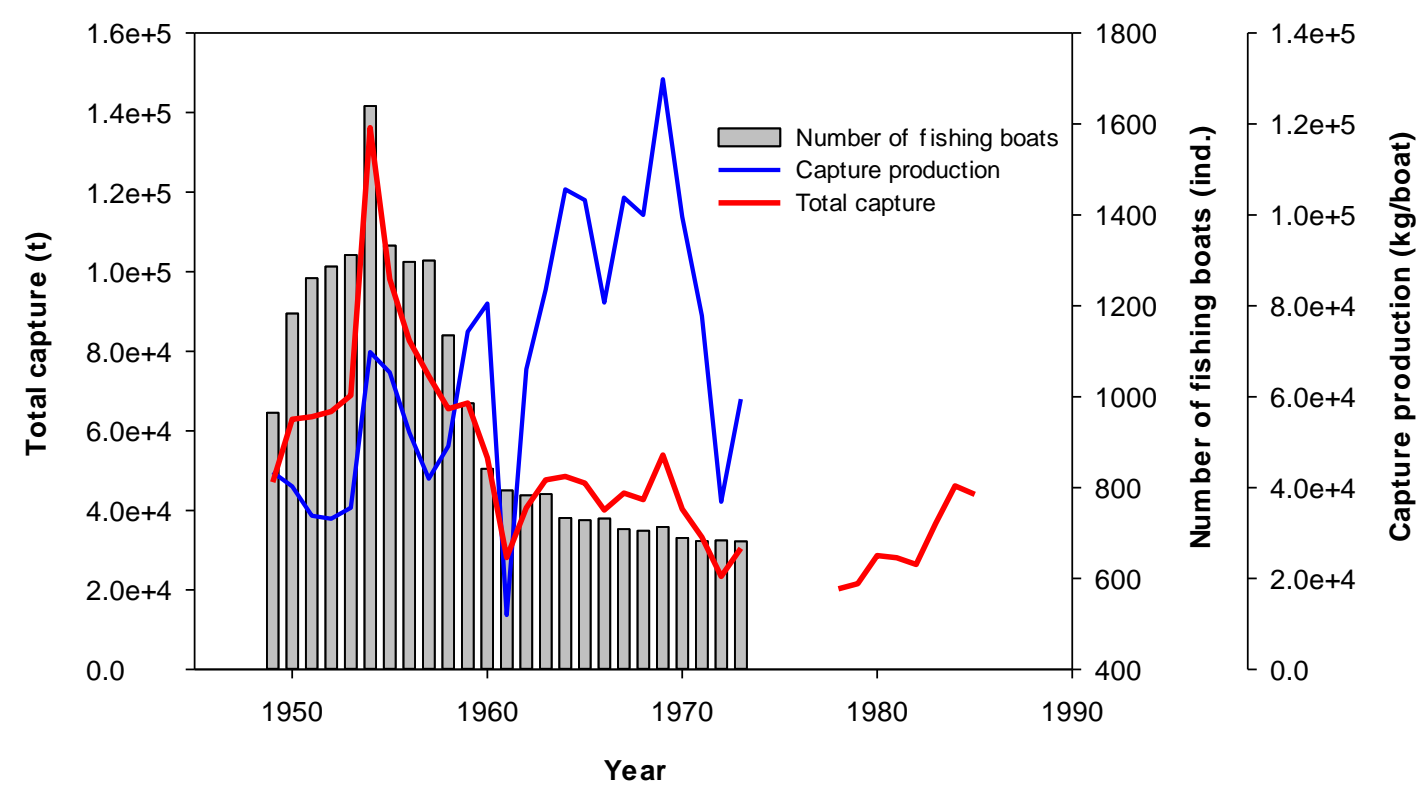

Figure 2. Fish capture production in Hubei Province (from Yichang to Hukou) before and after the construction of the Gezhouba Dam (SGFRYR, 1990)

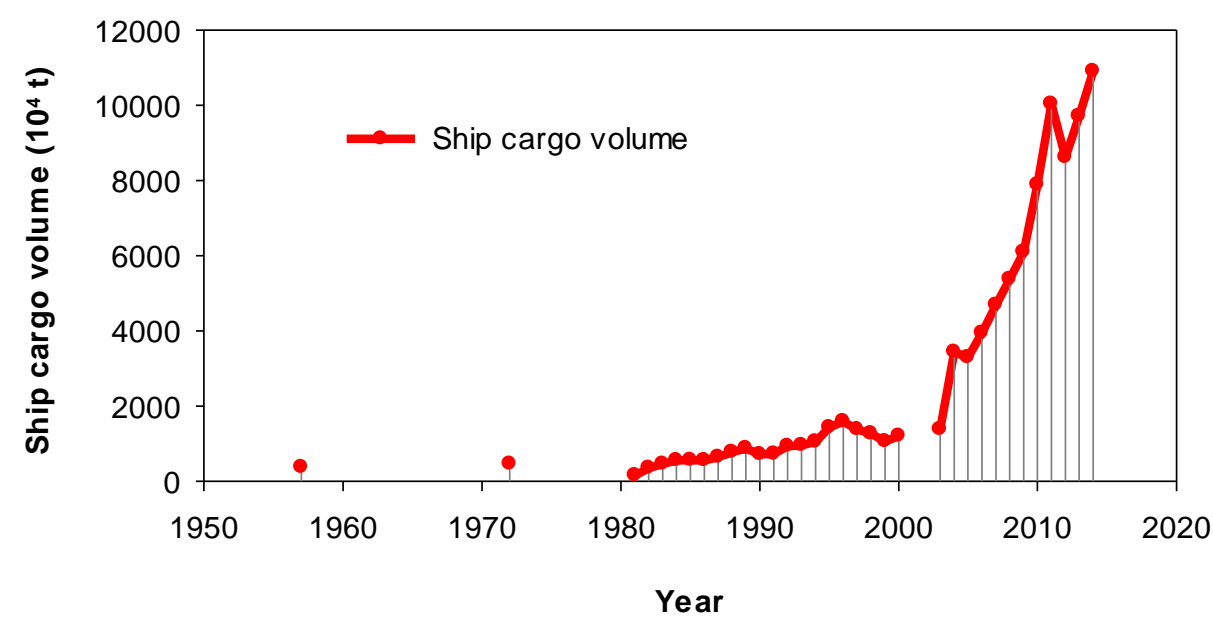

Figure 3. The ship cargo volume before and after the construction of the Gezhouba Dam. Few data were obtained before 1980, but it was known the data in 1957 and 1972 were historical peaks because of political reasons (Yin et al., 2002; CTGC, 2015) 


\section{Main ecological effects of the Gezhouba Dam}

\section{Influence pathways}

The main ecological effects of the Gezhouba Dam contain two aspects: 1) blocking the movement and migration of aquatic organisms directly, and 2) reservoir operation altered the river environment and then affected the aquatic organisms indirectly. Fig. 4 presents the detailed influence pathways of the Gezhouba Dam on aquatic organisms.

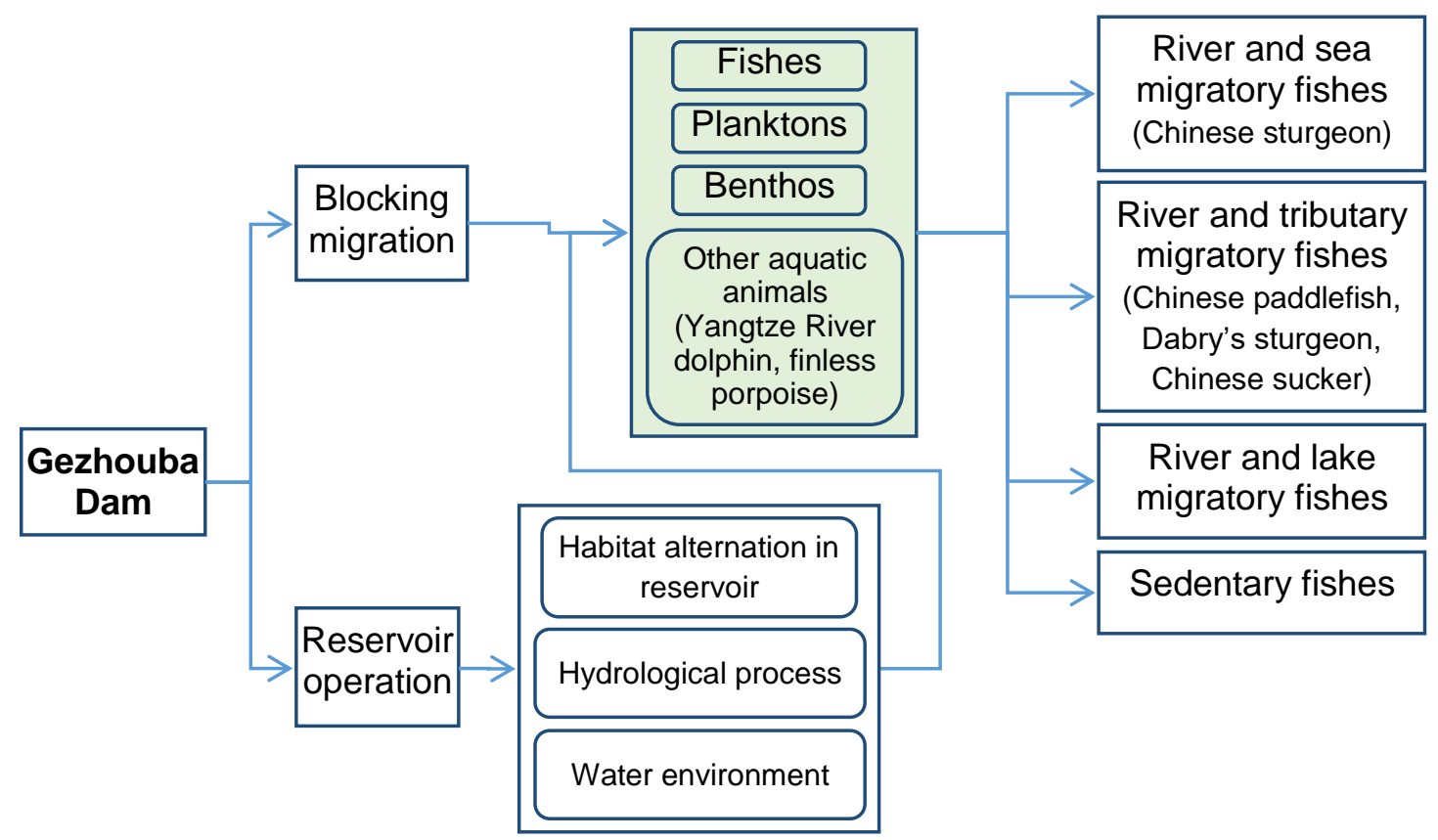

Figure 4. Ecological influence pathways of the Gezhouba Dam on Yangtze aquatic organisms (representative endangered species are showed in the brackets)

\section{Effects on fishes \\ Effects on fishery composition}

In both time periods between before and after the dam was constructed, the compositions of the fish fauna around the Yichang River section (above and below the Gezhouba Dam) were dominated by riverine and plain fish species. Hundred fish species were found before the dam closed while 94 species were observed after that closed on the basis of the investigations (WCPBHB, 1975; Wu et al., 1988). In the time after the dam was built, the proportion of fluvial fish in the reservoir area was slightly reduced, six fluvial fish species, for instance folifer brevifilis, were not found in the later investigation ( $\mathrm{Wu}$ et al., 1988). As the river environment below the dam had little change compared with that before the dam was constructed, the main commercial fishery species had not fundamentally changed. The majority of fish family such as Cyprinidae and Bagridae has been observed before the dam was built, and later the dam was constructed, Siluridae was founded (Wu et al., 1988). As a result of the dam's blocking, the number of migratory fishes increased below the dam, such as the Chinese sucker. The proportion of the major economic fishes in the catch composition varied slightly, more precisely nine species such as leiocassis longirostris were increased. 
However, the fishery resources in the Yangtze River occurred decline trend at that time. Overall, the dam had no obvious effects on the harvest of fish production in the Yichang section (Wu et al., 1988).

\section{Effects on river and sea migratory fishes}

Three typical fish species belong to this category: the Chinese sturgeon and Reeves shad are anadromous, and the Japanese eel is diadromous. The Chinese sturgeon has been greatly affected by the Gezhouba Dam (Wei et al., 1997). Firstly, its migration route was completely blocked, approximate $1,100 \mathrm{~km}$ of migration route in the upper Yangtze River was not accessible. Accordingly, the spawning areas originally in that reach could not function at all. Although new spawning activities have been documented below the dam since 1982 (Chang et al., 1998), the number of spawning areas and spawning scale were significantly decreased compared with those before constructing the dam. More than 16 spawning areas had been reported in the $600 \mathrm{~km}$ historical spawning reach but only 2-3 new spawning areas were reported in the $30 \mathrm{~km}$ reach below the dam (Zhang et al., 2009). Moreover, the spawning scale was greatly decreased. Secondly, blocking made many Chinese sturgeon aggregated below the dam and over exploited by fishing. In 1981-1982, fishing on the species was not prohibited, and approximately 1,805 adults were captured which made the natural population of the species incurred a great loss (Wei et al., 1997). Thirdly, the adult population below the dam was significantly deteriorated due to the altered inhabiting environments. For instance, the sex ratio (female to male) was used to be 1:1 before constructing the dam, however it gradually became 5.86:1 in 2003-2004, which probably caused a very low spawning success rate (Wei et al., 2005). Moreover, approximately $40 \%$ adults appeared difficulties in gonadal development (Wei et al., 1997; Xiao et al., 2006). Clearly, the breeding population was ageing and the number of recruitment adult individuals became very small (Wei, 2003; Wei et al., 2005). Fourthly, as the migration route of the adults was greatly shortened, that is approximately $1,100 \mathrm{~km}$, correspondingly, the living area for the filial generation of the species was considerably reduced by about $40 \%$ (Zhang et al., 2012).

On the other hand, historically, only a few of Reeves shad and Japanese eel had been found above Yichang. It was speculated that only a few of them would have migrated into the reach above the dam site. Based on the variations of capture on the two species since 1980s, the two were more affected by other anthropogenic activities such as overfishing and destruction of spawning areas. Hence, it was concluded that the Gezhouba Dam had little adverse effects on these two species (FLIHHP, 1976; SGFRYR, 1990).

\section{Effects on river and tributary migratory fishes}

The typical species which belong to this category include Chinese paddlefish, Dabry's sturgeon, Chinese sucker, brass gudgeon Coreius heterokon, and largemouth bronze gudgeon $C$. guichenoti. In fact, the life history of Chinese paddlefish and Dabry's sturgeon had not been fully understood (YARSG, 1988; Zhang et al., 2009, 2011). In general, they were regarded to be migrated to the Yangtze main stream (from upstream to estuary) and the tributaries. Their spawning areas were speculated to be located in the upstream near Yibin. After blocking the Gezhouba Dam in 1981, the two species were captured below the dam (Wei et al., 1997). In earlier 1980s, approximate 
10-30 paddlefish in every year were caught according to the capture records. However, the catch record decreased less than 10 individuals in earlier 1990s. Since 1995, no capture record was found. The capture record on Dabry' sturgeon showed the similar to that of the paddlefish (Wei et al., 1997). It was concluded that the number of two species has been extremely affected by the Gezhouba Dam.

The Minjiang River, a tributary in the upper Yangtze reach, was well-known as the spawning area of Chinese sucker. The construction of the Gezhouba Dam blocked its migration. Five new spawning areas for the Chinese sucker were reported below the dam in 1980s (Liu et al., 1992). However, since the 1990s, the natural spawning activity of the species was not documented in the entire Yangtze Basin. On the basis of the incidental capture records of adults, the natural population of the fish was notably declined. The Gezhouba Dam was considered to be one of the most important factors for the decline of this species.

The external morphology and migration behavior between Brass gudgeon and largemouth bronze gudgeon are very close. However, the spawning area of Brass gudgeon was widely distributed in the entire Yangtze main stream, while that of large mouth bronze gudgeon was only in the lower Jinsha River. The spawning area of Brass gudgeon was not largely changed although the Gezhouba Dam blocked its migration route (Liu et al., 1990). However, the only spawning area of largemouth bronze gudgeon was found in the upper Yangtze reach, the breeding population of this species was largely blocked at below the dam. It can be assumed that the spawning activities of this fish had been greatly affected by the dam.

\section{Effects on river and lake migratory fishes}

The typical species for this category are four major Chinese carps, as well as some other economically important fish species. Taking the four carps for instance, the number of spawning area and the estimation of spawning scale were remarkably decreased since the Gezhouba Dam was closed in 1981 (Table 3).

Table 3. Spawning variations of the four major Chinese carps before and after the closure of the Gezhouba Dam in the Yangtze River on January 4th 1981

\begin{tabular}{c|c|c|c|c}
\hline $\begin{array}{c}\text { Survey } \\
\text { time }\end{array}$ & Survey reach & $\begin{array}{c}\text { Number of } \\
\text { spawning areas } \\
\text { (ind.) }\end{array}$ & $\begin{array}{c}\text { Number of } \\
\text { estimated eggs } \\
\text { and larvae }(\times \mathbf{1 0})\end{array}$ & References \\
\hline $1964-1965$ & $\begin{array}{c}\text { Chongqing-Pengze } \\
(1695 \mathrm{~km})\end{array}$ & 36 & 1183.7 & Yi et al., 1988 \\
1981 & $\begin{array}{c}\text { Chongqing-Wuxue } \\
(1520 \mathrm{~km})\end{array}$ & 24 & 173 & $\begin{array}{c}\text { SGSAYFMCC, } \\
1982\end{array}$ \\
1986 & $\begin{array}{c}\text { Chongqing-Tianjiazhen } \\
(1460 \mathrm{~km})\end{array}$ & 30 & 175.5 & Yu et al., 1988 \\
2015 & Jingkou-Huangshi & 15 & 11.4 & YRFA, 2016 \\
\hline
\end{tabular}

The number of spawning area decreased by $20.0-33.3 \%$, while the spawning scale decreased approximately 16.0\% (from 1964-1965 to 1981 and 1986). In consideration with the entire Yangtze River, the spawning locations were not largely alternated. However, the spawning areas around the dam were destroyed, and the spawning areas were divided above and below the dam (SGSAYFMCC, 1982; Yi et al., 1988; Yu et al., 1988). Furthermore, hereafter the Three Gorges Dam started to be operated in 2002, the 
spawning scale decreased further to 11.4 billion in 2015 (YRFA, 2016). It was concluded that the original assessment on the effects of the dam for four carps was appropriate. However, the decline of the fish natural population was far beyond the previous judgements since various and fast developing anthropogenic activities threatened the species. An example of anthropogenic activities was that some lakes turned into farming fields. Other examples could be fishing and water pollution (SGFRYR, 1990).

\section{Effects on sedentary fishes}

Except for the reservoir area, the environmental conditions of other river sections were not changed. Thus, the distribution of the species in the river sections were not largely altered. The environmental alternations of the reservoir increased lentic fishes, yet reduced lotic fishes. However, there was only little effect on all resources of the settlement fishes (Huang, 2002), such as the common carp Cyprinus carpio and crucian carp Carassius auratus.

\section{Effects on phytoplankton}

In either above or below the dam, the species composition and biomass of phytoplankton were analogous to before and after the dam was constructed. The dominated species were Bacillariophyta, Chlorophyta, and Cyanophyta. Only in the Huangbohe Reservoir, the biomass of phytoplankton was higher than that in the original natural river (Huang, 2002).

\section{Effects on zooplankton}

The protozoan was dominant species in terms of species number, however, the copepod was the most abundant species which means it had the highest biomass. The distribution and biomass of the zooplankton were similar before and after the dam was constructed, the dominant species seemed to be nearly same (Huang, 2002).

\section{Effects on benthos}

The species and biomass of benthic organisms were very related with the river ecological environments such as water depth, substrate, water flow, water quality and food supply (plankton). As the Gezhouba Dam was a low-head run-off hydropower plant, it did not greatly change the river flowing environment. This reach was in the gorges with step riversides so that there were a few riparian areas. Hence, the benthic organisms have not been extremely influenced. Only in the Reservoir, the dominated species of benthic organisms was changed into Oligochaeta (Huang, 2002).

\section{Effects on aquatic vascular plant}

The aquatic vascular plants near the dam were relatively poor conditions either before or after the dam construction since this reach was in the gorges and had a few riparian areas as well as high fluctuation of water level and high sediment content. Therefore, it was concluded that the dam had little influence on the aquatic vascular plant. 


\section{Effects on other aquatic animals}

Other aquatic animals affected by the dam could be Yangtze River dolphin, finless porpoise, and Chinese giant salamander. Their life history could be influenced by the dam. The Yangtze River dolphin was reported to be distributed from Huanglingmiao (a site at Yichang reach, approximately $30 \mathrm{~km}$ upstream the dam) to the Yangtze estuary, that is approximate $1800 \mathrm{~km}$ in river length (Chen et al., 1997). The finless porpoise was distributed in the river reach below Yichang to Yangtze estuary which is approximately $1700 \mathrm{~km}$ in river length (Chen et al., 1997). The Gezhouba Dam was almost at the top of the upstream living area for the Yangtze River dolphin and finless propose. Accordingly it should not have considerable adverse effects on the two aquatic animals. The Chinese giant salamander is mainly distributed in the mountainous tributaries and stream. The Gezhouba Dam was a low-head run-off hydro power plant located in the main stem, and the reservoir was relatively small, the backwater did not greatly affect the tributaries. Therefore the dam did not have significant influence on the Chinese giant salamander.

\section{Conservation measures}

Because of the construction of the Gezhouba Dam, many protective measures have been adopted to reduce the adverse effects on Yangtze fishes. The main mitigated measures included catching and moving the Chinese sturgeon to the upstream, building a Chinese sturgeon hatchery, and conducting artificial propagation and releasing. In addition, in view of increasingly adverse impacts of various anthropogenic activities on the Yangtze aquatic biodiversity, other protective measures such as natural population protection, habitat protection, fishing ban policy, and special rescue plan for flagship species have also been adopted.

\section{Catching the sturgeons below the dam and moving them above the dam}

After the closure of the dam in 1981, many Chinese sturgeons were concentrated in the $20-\mathrm{km}$ reach below the dam. To help the species to distribute above the dam, a number of the species were captured and moved to the upstream area by boats or trucks (Liu and Xiao, 1993). The fixed or drifting gill nets and setlines were used to capture the species. Fishing was highly affected by water level, discharge, and water temperature. In summer, it was difficult to catch due to high water level and vast flow discharge. In winter, the species moved less than other seasons because of low temperature, thus it was not easy to catch them. The good fishing seasons were spring and autumn, especially in autumn, the sturgeons were tended to be aggregated. When the river flow reduced to $8,000-20,000 \mathrm{~m}^{3} / \mathrm{s}$, it was the best time for fishing operations. In the catch, the mature individuals (gonad for stage IV) were used for artificial propagation, and immature individuals (gonad for stage III) were transported to upper area from the dam or kept for culturing them. The transportation of the sturgeons was carried out for four years (Liu and Xiao, 1993). The captured brood stock was placed in a temporary canvas basket with water, and then transported by a boat or truck to the upper reservoir area. During 1982-1985, a total of 40 individuals, with male and female ratio of 1: 1.2, were transported for trial purpose. It was concluded that transporting a number of the species over the dam to "save the species" had little significance. In fact the transported population was very small which was not enough to form spawning 
activities. To enable to form a breeding population in the upstream, a large amount of fishing was required. At that time, it was perceived that a great number of catching and transporting the species required very high costs and heavy workloads. Finally, the transportation of the species was stopped since 1986 when the spawning activity of Chinese sturgeon was documented below the dam in 1982.

\section{Hatchery construction and artificial releasing program}

In 1982, the state authorities set up the Chinese sturgeon Institute in Yichang, which charged specially for the controlled reproduction and release of this endangered species (Liu and Xiao, 1993). This was another mitigated measure to compensate for the negative effects of the Gezhouba Dam which imposed on natural reproduction of the sturgeon. In addition, sturgeons were released in both protect areas located in the Yichang and Shanghai regions by relevant enterprises and research institutes (MOA, 2015). Up to now, over six million Chinese sturgeons of different sizes (mostly less than $35 \mathrm{~cm}$ ) have been released by the relevant units. The released sites were mainly in the middle reaches of the Yangtze River, the Yangtze River Estuary, the Pearl River, and the Minjiang River as well as other waters to support the remaining population by restocking. However, although the artificial releasing has been conducted for more than 30 years, results have not been thoroughly evaluated. A reason can be the difficulty of monitoring them in a vast spatiotemporal range. In early 21 century, only a few research indicated that more than $90 \%$ of the juveniles in Yangtze estuary was originated from natural reproduction (Zhu et al., 2002; Wei, 2003; Yang et al., 2005). Both markrecapture and molecular genetic methods showed the similar results to the above one. That means the artificial enhanced program was of limited significance and needed further improvements.

The optimistic aspect was that many Chinese sturgeons in different ages have been stored for the controlled propagation and releasing practices. Among them, a certain number of specimens have reached sexual maturity ( 8 years old). The mechanism of rescuing individuals suffered from accidental by-catch or injury was clearly understood. The mechanism was used to conduct artificial reproduction. Moreover, the artificial propagation technique of Chinese sturgeon was succeed since 2009 (Guo et al., 2011; Wei et al., 2013), which allows to sustain the species in complete artificial environments. It built a good foundation for natural population enhancement, as the artificial propagation and releasing can independent of natural mature individuals, which means natural population can purely and largely be supported by artificial population.

\section{Prohibition of fishing and listed as protected animals}

As a large number of Chinese sturgeon was captured after the Gezhouba Dam blocked its migration route in 1981 and 1982, a total ban on commercial fishing of the species was implemented since 1983 (MOA, 2015). In 1989, the species was listed as one of the top-level protected animals in China. In 1996, the species was registered as an Endangered (EN) species on the Red List of the International Union for Conservation of Nature (IUCN). Later in 2010, the species was upgraded as a Critical Endangered (CR) species in the Red List. In 1998, the species was also included in the Appendix II of the Convention on International Trade in Endangered Species of Wild Fauna and Flora (CITES). Prohibition of fishing and listed as an important protected species protected this species directly and remarkably. 


\section{Critical habitat protection and protected area constructions}

To protect the only known spawning area, that is below the Gezhouba Dam, and to breed cohorts of Chinese sturgeon, the "Yangtze Provincial Nature Reserve for Chinese Sturgeon" was established in 1996 in Yichang, Hubei Province (MOA, 2015). To protect the sturgeon juveniles and their feeding grounds along the Yangtze River estuary, the "Yangtze Estuary Nature Reserve for Chinese Sturgeon in Shanghai" was established in 2002. Some other protected areas were also set along the middle and lower reaches of the Yangtze River. For example, the "National Nature Reserve for Baiji in Xinluo Section of the Yangtze River in Hubei" played a positive role in the protection of this species and its habitats.

\section{Fishing ban policy}

Since 2003, the fishing ban policy was executed in the Yangtze Basin. In the Yangtze main stream from Deqin County, Yunnan Province to the Gezhouba Dam and some tributaries such as Min River, Jialing River, Wu River, and Chishui River (Fig. 1), fishing was forbidden from 12 o'clock of February 1 to 12 o'clock of April 30 every year. In the Yangtze main stem from the Gezhouba Dam to Yangtze River estuary, and Hanjiang River, as well as Dongting lake and Poyang lake, fishing was prohibited from 12 o'clock of April 1 to 12 o'clock of June 30 in each year. In December 23, 2015, the Ministry of Agriculture announced to enforce the fishing ban policy. The fishing ban area in the Yangtze main stem was extended into a longer stretch from Qumalai County, Qinghai Province to the estuary. Tributaries for example Tuo River, Dadu River, and Huai River were included. Moreover, the fishing period in the whole Yangtze Basin was unified into a four-month period from 0 o'clock of March 1 to 24 o'clock of June 30 every year. The fishing ban area and time period cover nearly all spawning areas and time periods of major fish species in the Yangtze River. Hence, it protected the breeding populations and their spawning activities very effectively. Below the Gezhouba Dam, the spring spawning species and their spawning activities could be well protected. However, the autumn spawning species, such as the Chinese sturgeon, was outside the fishing ban period.

\section{Flagship species protection}

In consideration with the fact that few rare and endemic species are on the verge of extinction, the Chinese government has exclusively designed protection measures on these species, such as Chinese sturgeon and Yangtze finless porpoise. Some decree documents issued to upgrade the Finless porpoise as a Class I protected animal. The central government also designed a very long period rescue plan for them, such as "The Action Plan for Conservation of the Chinese Sturgeon (2015-2030)" (MOA, 2015) and "The Action Plan for Conservation of the Yangtze finless porpoise (2016-2025)". Take the action plan for Chinese sturgeon as an example, it includes in-situ and ex-situ conservation actions, conservation action for genetic resources and supporting actions. The action plans will be used as guidelines and will play a very important role for future conservation of the two species. 


\section{Conclusions and conservation recommendations}

In summary, the original judgement regarding the ecological effects of the Gezhouba Dam on Yangtze aquatic organisms was appropriate. However, after the construction of Gezhouba Dam, the economic and social environments of the Yangtze River Basin have been undergone in great developments. The adverse effects of various anthropogenic activities on the Yangtze aquatic ecosystem have become more intensive and extensive (Zhang et al., 2016). Although some protective measures have been taken, the current aquatic biodiversity and fishery resources of the Yangtze River are still declining rapidly (Yang et al., 2007). Currently, the impacts of the Gezhouba Dam on aquatic biodiversity in the Yangtze River would be of little significance because the anthropogenic activities and ecological environment of the Yangtze Basin have been undergone in great changes. Overall, to protect the Yangtze aquatic biodiversity, it is recommended to focus on the following five aspects of work.

1) To further enhance the fishing ban or even to prohibit fishing in the entire Yangtze Basin gradually. The four-month fishing prohibition period at present is not enough to protect the fish biodiversity. It is recommended to extend the prohibition period, or to have a very long prohibition period for example ten years, in that period, most of the fishes can reproduce for 2-3 generations. The prohibition area can be extended gradually, the nature protected area and aquatic resource protected area could be the first priority, then moved to the main stem and tributaries. Lastly the lakes, such as Dongting Lake and Poyang Lake, where fishing is still important for a great number of fishermen to earn their livings. It is believed that the enhanced fishing ban below the Gezhouba Dam $(80 \mathrm{~km}$ reach below the dam is a nature protected area in province level) will be of great importance to protect the migratory fish populations and their spawning activities.

2) To further strengthen habitat conservation and rehabilitation, the following action can be considered: the construction and management of protected areas, optimizing dam ecological dispatch, rehabilitating critical habitats and reconnecting of migratory channels.

3) To further enhance the protection of flagship species such as Chinese sturgeon and finless porpoise. The protection measures in the two action plans should be well performed in the future. It should be mentioned that with the emphasis on protection of these flagship species with extensive living space and long life-span, actually it can protect the whole Yangtze aquatic biodiversity.

4) To further strengthen the policy guidance to make artificial propagation and releasing more effectively, to control the alien species strictly to prevent biological invasion, and to revise the list of protected species.

5) Last yet not least, a watershed collaborative management mechanism is urgently needed. To enhance communication and cooperation between national and local administrative organizations along the Yangtze River, achievable and comprehensive improvement-oriented management for the basin environment should be accomplished.

Acknowledgements. The authors give special thanks to other members of Endangered Fishes Conservation Group of YFI, CAFS for assisting with the literature study. This study was supported by the National Natural Science Foundation of China (No. 51641909, 31711540294, 31602160), and the China Three Gorges Corporation (No. 0799564). This work was supported under the framework of international cooperation program managed by the National Research Foundation of Korea (2017K2A9A2A06015027, FY2017). 


\section{REFERENCES}

[1] Anonymous (1993): Introduction of the Gezhouba Dam in the Yangtze River. In: CHES, CSEE, CSHE (Chinese Hydraulic Engineering Society, Chinese Society for Electrical Engineering, China Society for Hydropower Engineering). Proceedings of the Gezhouba Water Conservancy Project. - China Water Power Press, Beijing, China: 7-9.

[2] Chang, J. B., Huang, Z. L., Cao, W. X. (1998): Arguments and inspirations on rescue measures of fishes for Gezhouba Dam in the Yangtze River. Huang, Z. L., Fu, B. J., Yang, Z. F. Ecological and Environmental Protection for Large Water Conservancy Projects in the Yangtze River in 21 Century. - China Environmental Science Press, Beijing, China: 186-198.

[3] Chen, P. X., Liu, R. J., Wang, D., Zhang, X. F. (1997): The Biology, Breeding and Protection of the Baiji. - Science Press, Beijing, China.

[4] CTGC (China Three Gorges Corporation) (2015): Operation Records of the Three Gorges Project (2003-2015). http://www.ctg.hk/sxjt/xwzx/snyxsl/index.html.

[5] CWRC (Changjiang Water Resources Commission) (2002): Review on design and verification of the Gezhouba Water Conservancy Project. In: Changjiang Water Resources Commission. Proceedings on the Gezhouba Water Conservancy Project. - The Yellow River Water Conservancy Press, Zhengzhou, China: 1-12.

[6] FLIHHP (Fish Laboratory, Institute of Hydrobiology, Hubei Province) (1976): Fishes in the Yangtze River. - Science Press, Beijing, China.

[7] Guo, B. F., Chang, J. B., Xiao, H., Zhu, B., Wan, J. Y., Tian, J. Y., Shu, D. B. (2011): The reproductive biology of first filial generation of Acipenser sinensis growing up in the freshwater environment. - Acta Hydrobiologica Sinica 35: 940-945.

[8] Huang, L. Z. (2002): Study on the fish rescue measures and its effects for the Gezhouba Project. Changjiang Water Resources Commission. Proceedings on the Gezhouba Water Conservancy Project. - The Yellow River Water Conservancy Press, Zhengzhou, China: 403-410.

[9] Liu, L. H., Wu, G. X., Wang, Z. L. (1990): Reproduction ecology of Coreius heterodon (Bleeker) and Coreius Guichenoti (Sauvage et Dabry) in the mainstream of the Changjiang River after the construction of Gezhouba Dam. - Acta Hydrobiologica Sinica 14(3): 205-215.

[10] Liu, L. H., Wu, G. X., Wang, Z. L., Yang, D. G. (1992): A effect of the Gezhou Dam key water control project on sexual gland development and natural spawning of Chinese sucker Myxocyprinus asiaticus in the downstream below the dam. - Journal of Fisheries of China 16(4): 346-356.

[11] Liu, Y., Xiao, H. (1993): Construction of the Gezhouba Project and conservation of Chinese sturgeon. In: CHES, CSEE, CSHE (Chinese Hydraulic Engineering Society, Chinese Society for Electrical Engineering, China Society for Hydropower Engineering). Proceedings of the Gezhouba Water Conservancy Project. - China Water Power Press, Beijing, China: 87-94.

[12] MOA, Ministry of Agriculture, China (2015): The Action Plan for Conservation of the Chinese Sturgeon (2015-2030). http://www.moa.gov.cn/govpublic/CJB/201510/t201510 12_4860909.htm.

[13] SGFRYR (Survey group on fishery resources in the Yangtze River) (1990): Fishery Resources of Yangtze River System. - China Ocean Press, Beijing, China.

[14] SGSAYFMCC (Survey Group on Spawning Areas of the Yangtze Four Major Chinese Carps) (1982): A survey on the spawning grounds of the "Four famous Chinese carps" in the Changjiang River after dammed by the key water control project at Gezhouba. Journal of Fisheries of China 6(4): 287-305.

[15] WCPBHB (Water Conservancy and Power Bureau in Hubei Province) (1975): Survey Report on Aquatic Resources in the Yangtze River, Hubei Province. - Water Conservancy and Power Bureau in Hubei Province, Wuhan, China. 
[16] Wei, Q. W. (2003): Reproductive behavioral ecology of Chinese sturgeon (Acipenser sinensis) with its stock assessment. - PhD thesis, Institute of Hydrobiology, Wuhan, China, $121 \mathrm{pp}$.

[17] Wei, Q. W., Ke, F. E., Zhang, J. M., Zhuang, P., Luo, J. D., Zhou, R. Q., Yang, W. H. (1997): Biology, fisheries, and conservation of sturgeons and paddlefish in China. Environmental Biology of Fishes 48: 241-255.

[18] Wei, Q. W., Li, L. X., Du, H., Zhang, X. Y., Xiong, W., Zhang, H., Shen, L., Wu, J. M., Zhang, S. H., Wang, C. Y., Li, C. J., Chai, Y., Li, Y. W., Qiao, X. M., Liu, Z. G., Gao, Y. P., Gan, F. (2013): Research on technology for controlled propagation of cultured Chinese sturgeon (Acipenser sinensis). - Journal of Fishery Sciences of China 20: 1-11.

[19] Wei, Q. W., Chen, X. H., Yang, D. G., Liu, J. Y., Zhu, Y. J., Zheng, W. D. (2005): Variations in spawning stock structure of Acipenser sinensis within 24 years since damming of Gezhouba Dam. - Journal of Fisheries Science of China 12(4): 452-457.

[20] Wu, G. X., Liu, L. H., Wang, Z. L. (1988): Fish fauna and fishery composition in Yichang reach below the Gezhouba Water Conservancy Project. - Freshwater Fisheries (3): 8-13.

[21] Xiao, H., Liu, D. H., Tang, D. M., Guo, B. F. (2006): Structural and quality changes in the spawning stock of the Chinese sturgeon Acipenser sinensis below the Gezhouba Dam (Yangtze River). - Journal of Applied Ichthyology 22(Suppl 1): 111-115.

[22] Yang, D. G., Wei, Q. W., Wang, K., Chen, X. H., Zhu, Y. J. (2005): Downstream migration of tag-released juvenile Chinese sturgeon (Acipenser sinensis) in the Yangtze River. - Acta Hydrobiologica Sinica 29: 26-30.

[23] Yang, G. S., Wen, L. D., Li, L. F. (2007): Yangtze Conservation and Development Report. - Changjiang Press, Wuhan, China.

[24] YARSG (Yangtze Aquatic Resources Survey Group) (1988): The Biology of the Sturgeons and Paddlefish in the Yangtze River and their Artificial Propagation. - Sichuan Scientific and Technical Publishing House, Chengdu, China.

[25] Yi, B. L., Yu, Z. T., Liang, Z. S., Shan, S. J., Xu, Y. G., Chen, J. X., He, M. J., Liu, Y. L., Hu, Y. Z., Deng, Z. L., Huang, S. W., Sun, J. Y., Liu, R. J., Xiang, Y. (1988): The distribution, natural conditions and breeding production of the spawning grounds of four famous freshwater fishes on the main stream on the Yangtze River. In: Yi, B. L., Yu, Z. T., Liang, Z. S. Gezhouba Water Control Project and Four Famous Fishes in Yangtze River. - Hubei Science and Technology Press, Wuhan, China: 1-46.

[26] Yin, W. Q., Wan, X. W., Zhu, Q. (2002): The Gezhouba Water Conservancy Project is a success in the river channelization. In: Yangtze River Water Resources Commission. Proceedings on the Gezhouba Water Conservancy Project. - The Yellow River Water Conservancy Press, Zhengzhou, China: 39-46.

[27] YRFA (Yangtze River Fisheries Administration) (2016): 2015 Yangtze River Fisheries Bulletin (Government report).

[28] Yu, W. C., Lu, J. Y. (2005): Evolution of the Yangtze River and its regulation. - China Water Power Press, Beijing, China.

[29] Yu, Z. T., Deng, Z. L., Xu, Y. G., Cai, M. Y., Zhao, Y., Liang, Z. S., Wang, N., Zeng, X. S. (1988): The present situation of the spawning grounds of the four Chinese domestic fishes in the Changjiang (Yangtze River) after construction of the Gezhouba water control project. In: Yi, B. L., Yu, Z. T., Liang, Z. S. Gezhouba Water Control Project and Four Famous Fishes in Yangtze River. - Hubei Science and Technology Press, Wuhan, China: 47-68.

[30] Yu, Z. T., Deng, Z. L., Zhou, C. S., Xu, X. G., Zhao, Y. (1985): Prognosis of the effects of the Gezhouba Hydroelectric Project on fish resources of the river Chang Jiang. - In: Chinese Ichthyological Society. Transactions of the Chinese Ichthyological Society (No. 4).Scientific Press, Beijing, China: 193-208. 
[31] Zhang, H., Wei, Q. W., Du, H., Li, L. X. (2011): Present status and risk for extinction of the Dabry's sturgeon (Acipenser dabryanus) in the Yangtze River watershed: a concern for intensified rehabilitation needs. - Journal of Applied Ichthyology 27: 181-185.

[32] Zhang, H., Wei, Q. W., Du, H., Shen, L., Li, Y. H., Zhao, Y. (2009): Is there evidence that the Chinese paddlefish (Psephurus gladius) still survives in the upper Yangtze River? Concerns inferred from hydroacoustic and capture surveys 2006-2008. - Journal of Applied Ichthyology 25(Suppl. 2): 95-99.

[33] Zhang, H., Wei, Q. W., Li, C., Du, H., Liao, W. G. (2012): Effects of high water level on the river residence period of juvenile Chinese sturgeon Acipenser sinensis in the Yangtze River. - Knowledge and Management of Aquatic Ecosystems 405: 02.

[34] Zhang, H., Wei, Q. W., Du, H. (2009): A bedform morphology hypothesis for spawning areas of Chinese sturgeon. - Environmental Biology of Fishes 84: 199-208.

[35] Zhang, H., Wu, J. M., Wang, C. Y., Du, H., Liu, Z. G., Shen, L., Chen, D., Wei, Q. W. (2016): River temperature variations and potential effects on fish in a typical Yangtze River reach: implications for management. - Applied Ecology and Environmental Research 14(4): 553-567.

[36] Zhu, B., Zhou, F., Cao, H., Shao, Z., Zhao, N., May, B., Chang, J. (2002): Analysis of genetic variation in the Chinese sturgeon, Acipenser sinensis: estimating the contribution of artificially produced larvae in a wild population. - Journal of Applied Ichthyology 18: 301-306. 